\title{
Effect of the microfauna composition on fermentation pattern in the rumen of sheep*
}

\author{
T. Michałowski, E. Kwiatkowska, G. Bełżecki and J.J. Pająk
}

\author{
The Kielanowski Institute of Animal Physiology and Nutrition. \\ Polish Academy of Sciences \\ 05-110 Jabtonna, Poland
}

\section{ABSTRACT}

Three Polish Merino sheep fed hay and ground barley were defaunated and then refaunated consecutively with only one (Eudiplodinium maggii), two (Eudiplodinitum maggii and Entodinium caudatum) or three (Eudiplodinium maggii, Entodinium caudatum and Dasytricha ruminantium) ciliate species. Both the concentration and production rate of total VFA as well as the proportion of individual acids were estimated before the morning fecding and $4 \mathrm{~h}$ thereafter. The concentration of VFA varied from 8.2 to $11.6 \mathrm{mM} / 100 \mathrm{ml}$ of rumen fluid and production rate from 29.1 to $34.1 \mu \mathrm{M} / \mathrm{g}$ rumen digesta/h in relation to the time after feeding.

Molar proportion of acetate, propionate and butyrate in the total VFA in the rumen or produced in vitro was $65.1-74.6,16.0-21.2$ and $9.1-11.8 \%$, respectively. The concentration of VFA as well as production rate and molar proportion of individual acids were influenced by ciliates and composition of the fauna. Presence of Eudiplodinium maggii in the rumen resulted in the highest proportion of butyrate at $4 \mathrm{~h}$ after feeding. Establishment of ciliates in the rumen of sheep was accompanied by the drop in acetate proportions.

No effect of ciliates on $\mathrm{pH}$ values before feeding was found whereas increase in the acidity of rumen fluid after feeding was affected by the fauna composition.

KEY WORDS; ciliates, sheep, VFA production, molar proportion

\section{INTRODUCTION}

Ruminant animals utilize volatile fatty acids (VFA) as the main source of energy in cellular metabolism. VFA are released from the cells of ruminal bacteria fungi and protozoa as end products of their carbohydrate metabolism. They are

\footnotetext{
* Supported by the State Committee for Scientific Research, Grant No. 5 PO6E03615
} 
intensively absorbed from the rumen and transported with the blood to the tissues and cells of the host. Investigations on pure species of rumen microbiota have shown large diversity in fatty acids formation (Stewart and Bryant, 1988; Williams and Coleman, 1997) but acetic, propionic and butyric acid were found to be the main acids in the rumen fluid at variety of feeding regimes (Owens and Goetsch, 1988).

Rumen ciliates play an important part in VFA production in the rumen (Michałowski, 1987) but carbohydrate metabolism of these organisms differ significantly among the species (Williams and Coleman, 1997). This suggest that microfauna composition could influence the fermentation pattern in the rumen, however more detailed information on the role of individual species is still lacking (Ivan et al., 2000)

The aim of this study was to examine the concentration and molar proportion of particular acids following refaunation of the defaunated sheep with selected species of ciliates as well as to estimate the production rate of VFA in relation to microfauna composition and time after feeding.

\section{MATERIAL AND METHODS}

Three growing male Polish Merino sheep weighing 40-43 $\mathrm{kg}$ at the beginning of the experiment were used. The animals were fitted with permanent rumen fistulae of about $10 \mathrm{~cm}$ in diameter. They were kept in separate pens with the solid walls and fed $750 \mathrm{~g}$ hay and $130 \mathrm{~g}$ ground barley every $12 \mathrm{~h}$ and had free access to water. The sheep were defaunated by the methods of Michałowski et al. (1999) for at least 40 days before the experiment has begun.

The study composed of four experimental periods. The sheep were either ciliate-free (Period 1) or refaunated with Eudiplodinium maggii alone (Period 2), with the latter ciliate species and Entodinium caudatum (Period 3) or with the both mentioned species plus Dasytricha ruminantium (Period 4). Both species from the family Ophryoscolecidae originated from in vitro cultures. Dasytricha ruminantium ciliates were picked from the rumen fluid of cow and introduced immediately to the rumen of sheep.

Rumen fluid for $\mathrm{pH}$ and VFA concentration measurements was sampled just before the morning feeding $(8 \mathrm{am})$ and $4 \mathrm{~h}$ thereafter. The samples of rumen digesta (about $200 \mathrm{~g}$ ) were taken at the same time points to determined the production rate of VFA and the protozoal numbers. The sampling began not earlier than 3 weeks following the sheep defaunation (Period 1) or the establishment of each protozoal population (Periods 2, 3 and 4). The sampling was repeated three times in the case of each animal on three different days of experimental period. The samples for VFA measurements were fixed with formic acid $(10: 1 \mathrm{v} / \mathrm{v})$ and centri- 
fuged at $20000 \mathrm{~g}$ for $30 \mathrm{~min}$. Volatile fatty acids were determined qualitatively and quantitatively by gas chromatography methods according to Ziołecki and Kwiatkowska (1973) in the supernatant fraction of the centrifuged samples. The number of ciliates was determined microscopically according to Michalowski (1975) using the rumen digesta fixed with $4 \%$ formalin solution $(1: 1 \mathrm{w} / \mathrm{v})$. The rumen fluid reaction was estimated using Beckman $390 \mathrm{pH}$-meter. Production rate of VFA was estimated by the modified method of Carrol and Hungate (1954). For this purpose the amples of rumen digesta $(20 \mathrm{~g})$ taken from the rumen and immediately diluted with $50 \mathrm{ml}$ of a warm $\left(40^{\circ} \mathrm{C}\right)$ buffer composed of $(\mathrm{mg} / 100 \mathrm{ml})$ : $\left(\mathrm{NH}_{4}\right)_{2} \mathrm{SO}_{4}-45 ; \mathrm{KH}_{2} \mathrm{PO}_{4}-45 ; \mathrm{K}_{2} \mathrm{HPO}_{4}-45 ; \mathrm{NaCl}-90 ; \mathrm{MgSO}_{4}$ - 9; $\mathrm{NaHCO}_{3}-750$; cysteine hydrochloride - 25 ; casitone - 100 ; yeast extract -100 ; thioglicolic acid 0.03 and sterilized rumen fluid $-30 \mathrm{ml}$. The samples were incubated anaerobically for $2 \mathrm{~h}$ at $40^{\circ} \mathrm{C}$ at a continuous mixing with a $\mathrm{CO}_{2}$ stream $(60 \mathrm{ml} / \mathrm{min})$. Concentration of VFA was measured just before start of incubation and then every $30 \mathrm{~min}$. Sample fixation and fatty acid determination methods were the same as described above. Production rate was calculated from the increase in the acid concentrations and expressed as $\mu \mathrm{M}$ acids/g rumen digesta/h. Mean values were calculated from the obtained results whereas Students' $t$ test was used to estimate the significance of differences between mean values.

\section{RESULTS AND DISCUSSION}

The animals were ciliate-free during the first experimental period (Table 1). Rumen ciliate fauna composed of only Eudiplodinium maggii during the second period and of Eudiplodinium maggii and Entodinium caudatum during the third. Dasytricha ruminantium and two latter species represented the protozoa during the last period of experiments. Of the species established in the rumen of sheep the first belongs to the group of strongly fibrolytic organisms whereas the second is starch preferring (Coleman, 1986; Dehority, 1993; Michałowski, 1997). In oppo-

TABLE 1

Ciliate numbers in consecutive periods of experiments (x $10^{3} / \mathrm{g}$ rumen content)

\begin{tabular}{lcccc}
\hline \multirow{2}{*}{ Item } & \multicolumn{4}{c}{ Experimental period } \\
\cline { 2 - 5 } & 1 & 2 & 3 & 4 \\
\hline Eudiplodinium maggii & 0.0 & $22.8 \pm 9.9$ & $11.8 \pm 4.0$ & $10.8 \pm 4.4$ \\
Entodinium caudatum & 0.0 & 0.0 & $268.7 \pm 66.1$ & $285.0 \pm 52.4$ \\
Dasytricha ruminantium & 0.0 & 0.0 & 0.0 & $53.4 \pm 31.1$ \\
Other ciliates & not present & not present & not present & not present \\
\hline
\end{tabular}

\pm standard deviation $(\mathrm{n}=9)$ 
site to the both ophryoscolecids Dasytricha ruminantium utilize only soluble carbohydrates (Van Hoven and Prins, 1977). Apart from difference in nutritional behaviour the species inoculated subsequently into the rumen of sheep differ significantly when carbohydrate fermentation pattern is taken into account (Williams and Coleman, 1997)

To study the changes in fermentation pattern the ciliates Eudiplodinium maggii, Entodinium caudatum and Dasytricha ruminantium were consecutively established in the rumen of each sheep and the total VFA concentration as well as production rate and the proportion of individual acids were examined. It was found that the concentration of VFA and molar proportion of individual acids was influenced by the time after feeding and composition of the ciliate fauna established in the rumen. The concentration of total VFA in defaunated animals increased significantly after feeding while the proportions of the acids did not change significantly (Table 2). In opposite to that the increase in the concentration of volatile fatty acids in refaunated animals was always accompanied by the decrease in molar proportion of acetate and by increase in this of propionate. A tendency to increase in the proportion of butyrate was also observed there but the statistically significant change was only noted when Eudiplodinium maggii was present in the rumen as the only ciliate species (Period 2). In other study the proportions of acetate and butyrate but not total VFA were influenced by the fauna composition (Ivan et al., 2000). Rumen fluid reaction before feeding was not affected by the presence of ciliates. However, the drop in $\mathrm{pH}$ value at $4 \mathrm{~h}$ after feeding was the smallest when only Eudiplodinium maggii was present in the rumen (Table 2).

Production rate of VFA varied between 29 and $34 \mu \mathrm{M} / \mathrm{g}$ rumen digesta/h. It tended to increase at $4 \mathrm{~h}$ after feeding but statistically significant change was

TABLE 2 Total concentration $(\mathrm{mmol} / 100 \mathrm{ml})$ and molar proportions $(\%)$ of particular acids in the rumen of defaunated and differently refaunated sheep just before $(0 \mathrm{~h})$ and $4 \mathrm{~h}$ after feeding $(n=9)$

\begin{tabular}{lcccccccc}
\hline \multirow{2}{*}{ Item } & \multicolumn{2}{c}{ Ciliate-free } & \multicolumn{2}{c}{ Eud. maggii } & $\begin{array}{c}\text { Eud. Maggii } \\
\text { Ent. caudatum }\end{array}$ & \multicolumn{2}{c}{$\begin{array}{c}\text { Eud. maggil, } \\
\text { Ent. caud. } \\
\text { D. ruminantium }\end{array}$} \\
\cline { 2 - 9 } & $0 \mathrm{~h}$ & $4 \mathrm{~h}$ & $0 \mathrm{~h}$ & $4 \mathrm{~h}$ & $0 \mathrm{~h}$ & $4 \mathrm{~h}$ & $0 \mathrm{~h}$ & $4 \mathrm{~h}$ \\
\hline Total VFA & $8.3^{\mathrm{a}}$ & $10.4^{\mathrm{a}^{* * *}}$ & $7.6^{\mathrm{a}}$ & $10.0^{\mathrm{a} * *}$ & $10.0^{\mathrm{b}}$ & $11.6^{\mathrm{b**}}$ & $8.2^{\mathrm{a}}$ & $9.6^{\mathrm{a} *}$ \\
Acetate & $68.9^{\mathrm{a}}$ & $67.1^{\mathrm{a}}$ & $71.9^{\mathrm{ab}}$ & $65.1^{\mathrm{a} *}$ & $71.8^{\mathrm{a}}$ & $68.9^{\mathrm{a} * *}$ & $73.4^{\mathrm{b}}$ & $71.3^{\mathrm{a} *}$ \\
Propionate & $19.9^{\mathrm{a}}$ & $21.2^{\mathrm{a}}$ & $17.6^{\mathrm{ab}}$ & $21.1^{\mathrm{ab} * *}$ & $17.5^{\mathrm{ab}}$ & $19.9^{\mathrm{ab} *}$ & $17.4^{\mathrm{ab}}$ & $18.9^{\mathrm{b}}$ \\
Butyrate & $11.2^{\mathrm{a}}$ & $11.7^{\mathrm{a}}$ & $10.5^{\mathrm{ab}}$ & $13.8^{\mathrm{b} * *}$ & $10.7^{\mathrm{a}}$ & $11.2^{\mathrm{a}}$ & $9.2^{\mathrm{b}}$ & $9.8^{\mathrm{ac}}$ \\
pH & $6.86^{\mathrm{a}}$ & $6.19^{\mathrm{a}}$ & $6.85^{\mathrm{a}}$ & $6.59^{\mathrm{b}}$ & $6.78^{\mathrm{a}}$ & $6.15^{\mathrm{a}}$ & $6.89^{\mathrm{a}}$ & $6.23^{\mathrm{a}}$ \\
\hline
\end{tabular}

values in a row with different letters (normal or bold, respectively) differ significantly significance of difference between the values of the same experimental period is market by asterisk $* \mathrm{P}<0.05 \quad * * \mathrm{P}<0.01 \quad * * * \mathrm{P}<0.001$ 
found only following development of Eudiplodinium maggii in the rumen of defaunated sheep (Table 3 ). The proportion of acetate produced tended to decrease after feeding. No significant differences were, however, found there. Proportion of propionate increased in defaunated and refaunated with Eudiplodinium maggii and Entodinium caudatum sheep. An increase by about $29 \%$ in the proportion of butyrate was found following the development of Eudiplodinium maggii in the rumen of defaunated sheep. This finding correlate well with high proportion of butyrate produced by pure cultures of this protozoan in vitro in absence of bacteria (Michałowski, 1997). Similar changes in proportion of butyrate in VFA produced by the microfauna composed of three species of ciliates were also found and they were accompanied by a decrease in acetate proportion. This last relationship seems to be the result of development of population of the ciliate species inoculated in the rumen.

TABLE 3

Production rate of total VFA ( $\mu \mathrm{M} / \mathrm{g}$ rumen digesta/h) and molar proportion of particular acids (\%) produced during in vitro incubation of digesta taken just before $(0 \mathrm{~h})$ or $4 \mathrm{~h}$ thereafter from the rumen of defaunated and differently refaunated sheep $(n=9)$

\begin{tabular}{llccccccc}
\hline \multirow{2}{*}{ Acids } & \multicolumn{2}{c}{ Ciliate-free } & Eud. maggii & $\begin{array}{c}\text { Eud. Maggii } \\
\text { Ent. caudatum }\end{array}$ & \multicolumn{2}{c}{$\begin{array}{c}\text { Eud. maggii, } \\
\text { Ent. caud. } \\
\text { D. ruminantium }\end{array}$} \\
\cline { 2 - 10 } & $0 \mathrm{~h}$ & $4 \mathrm{~h}$ & $0 \mathrm{~h}$ & $4 \mathrm{~h}$ & $0 \mathrm{~h}$ & $4 \mathrm{~h}$ & $0 \mathrm{~h}$ & $4 \mathrm{~h}$ \\
\hline Total VFA & $31.8^{\mathrm{a}}$ & $33.4^{\mathrm{a}}$ & $30.4^{\mathrm{a}}$ & $34.1^{\mathrm{a}}$ & $29.1^{\mathrm{a}}$ & $32.7^{\mathrm{a}}$ & $30.7^{\mathrm{a}}$ & $33.1^{\mathrm{a}}$ \\
Acetate & $72.8^{\mathrm{ab}}$ & $69.0^{\mathrm{ab}}$ & $70.4^{\mathrm{a}}$ & $68.0^{\mathrm{a}}$ & $73.2^{\mathrm{ab}}$ & $70.3^{\mathrm{ab}}$ & $74.6^{\mathrm{b}}$ & $72.1^{\mathrm{b}}$ \\
Propionate & $16.0^{\mathrm{a}}$ & $20.0^{\mathrm{ab}}$ & $17.8^{\mathrm{a}}$ & $17.2^{\mathrm{a}}$ & $16.0^{\mathrm{a}}$ & $19.0^{\mathrm{ab}}$ & $16.3^{\mathrm{a}}$ & $16.5^{\mathrm{b}}$ \\
Butyrate & $11.2^{\mathrm{a}}$ & $11.0^{\mathrm{a}}$ & $11.8^{\mathrm{a}}$ & $14.8^{\mathrm{b}}$ & $10.8^{\mathrm{a}}$ & $11.7^{\mathrm{a}}$ & $9.1^{\mathrm{b}}$ & $11.4^{\mathrm{a} \cdots}$ \\
\hline
\end{tabular}

values in a row with different letters (normal or bold, respectively) differ significantly

significance of difference between the values of the same experimental period is marked by asterisk

$* \mathrm{P}<0.05 \quad * * \mathrm{P}<0.01 \quad * * * \mathrm{P}<0.001$

\section{REFERENCES}

Carroll E.J., Hungate R.E., 1954. The magnitude of the microbial fermentation in the bovine rumen. Appl. Microbiol. 2, 205-214

Coleman G.S., 1996. The amylasae activity of 14 species of entodiniomorphid protozoa and the distribution of amylase in digesta fractions of sheep containing no protozoa or one of seven different protozoal populations. J. Agr. Sci. 107, 709-721

Dehority B.A., 1993. Microbial ecology of cell wall fermentation. In: H.G. Jung, D.R. Buxton, R.D. Hatfield, J. Ralph (Editors). Forage Cell Wall Structure and Digestibility. ASA, Inc., CSSA, Inc., SSSA, Inc., Madison, Wisconsin (USA), pp. 425-453 
Ivan M., Neill L., Forster R., Alimon R., Rode L.M., Entz T., 2000. Effects of Isotricha, Dasytricha, Entodinium and total fauna on ruminal fermentation and duodenal flow in wethers fed different diets. J. Dairy Sci. 83, 776-787

Michałowski T., 1975. Effect of different diets on the diumal concentration of ciliate protozoa in the rumen of water buffalo. J. Agr. Sci. 85, 145-150

Michałowski T., 1987. The volatile fatty acids production by ciliate protozoa in the rumen of sheep. Acta Protozool. 26, 334-345

Michałowski T., 1997. Digestion and fermentation of the microcrystalline cellulose by the rumen ciliate protozoon Eudiplodinium maggii. Acta Protozool. 36, 181-185

Michałowski T., Harmeyer J., Bełżecki G., 1999. The importance of washing the omasum for successful defaunation of sheep. J. Anim. Feed Sci. 8, 611-619

Owens F.N., Goetsch A.L., 1988. Ruminal fermentation. In: D.C. Church (Editor). The Ruminant Animal Digestive Physiology and Nutrition. A Reston Book Prentice Hall, Englewood Cliffs., pp. $145-171$

Stewart C.S., Bryant M.P., 1988. The rumen bacteria. In: P.N. Hobson (Editor). The Rumen Microbial Ecosystem. Elsevier Applied Sci. London, New York, pp. 21-75

Van Hoven W., Prins R.A., 1977. Carbohydrate fermentation by the rumen ciliate Dasytricha ruminantium. Protostologica 13, 92-97

Williams A.G., Coleman G.S., 1997. The rumen protozoa. In: P.N. Hobson, C.S. Stewart (Editors). The Rumen Microbial Ecosystem. Blackie Academic and Professional, London, pp. 73-139

Ziolecki A., Kwiatkowska E., 1973. Gas chromatography of C1 to C5 fatty acids in rumen fluid and fermentation media. J. Chromatogr. 80, 250-254

\section{STRESZCZENIE}

\section{Wpływ skladu mikrofauny na przebieg fermentacji w żwaczu owiec}

Trzy owce Merynosa Polskiego, żywione sianem i śrutą jęczmienną zdefaunowano, a następnie refaunowano picrwotniakami z gatunku Eudiplodinium maggii, Eudiplodinium maggii i Entodinium caudatum lub Eudiplodinium maggii, Entodinium caudatum i Dasytricha ruminantium. U tak przygotowanych zwierząt mierzono stężenie lotnych kwasów tłuszczowych (LKT), tempo ich produkcji oraz proporcje molowe poszczególnych kwasów. Pomiarów dokonywano przed porannym karmieniem i w 4 godziny po odpasie. Stwierdzono, że stężenie LKT wahało się od 8.2 do $11.6 \mathrm{mmol} / 100 \mathrm{ml}$ płynu żwacza, a tempo ich produkcji od 29.1 do $34.1 \mu \mathrm{moli} / \mathrm{g}$ treści żwacza/h w zależności od czasu po karmieniu. Proporcje molowe: octanu, propionianu i maślanu w LKT płynu żwacza oraz w LKT produkowanych podczas inkubacji treści in vitro wynosiły odpowiednio 56.1-74.6, 16.0-21.2 i 9.1-11.8\% Zarówno stężenie LKT jak i tempo produkcji oraz proporcje molowe kwasów zależały od obecności orzęsków i składu fauny żwaczowej. U owiec z rozwiniętą populacją Eudiplodinium maggii stwicrdzono najwiçkszy udział kwasu masłowego i najmniejszy octowego w próbach pobieranych 4 h po karmieniu. Rozwojowi populacji orzęsków towarzyszyl spadek stężenia octanu w płynie żwacza. Nie stwierdzono wpływu obecności pierwotniaków na pH płynu żwacza przed karmieniem zwierząt. Wzrost kwasowości płynu po karmieniu zależal od składu fauny żwaczowej. 